\title{
Correlation between Robinson's cytological grading with Modified Bloom-Richardson histopathological grading for Breast carcinoma
}

\author{
Chalise $\mathrm{S}^{1}$, Jha $\mathrm{A}^{2}$, Neupane $\mathrm{PR}^{3}$, Pradhan $\mathrm{SB}^{4}$, Pathak R \\ ${ }^{I}$ Departmant of Pathology, Kathmandu Medical College, Sinamangal and Bhaktapur Cancer Hospital, Bhaktapur, Nepal. \\ ${ }^{2}$ Department of Pathology, Institute of Medicine, Maharajgunj and Bhaktapur Cancer Hospital, Bhaktapur, Nepal. \\ ${ }^{3}$ Departmant of Surgery, Bhaktapur Cancer Hospital, Bhaktapur, Nepal. \\ ${ }^{4}$ Departmant of Pathology, Kathmandu Medical College, Sinamangal, Nepal. \\ ${ }^{5}$ Department of Pathology, Nepal Medical College, Jorpati and Bhaktapur Cancer Hospital, Bhaktapur, Nepal.
}

\section{Keywords: \\ Fine needle aspiration cytology; \\ Robinson's cytological grading; \\ Modified Bloom-Richard- son grading.}

\begin{abstract}
Background: Invasive breast carcinoma is the most common carcinoma in women. Fine needle aspiration cytology is the important part of triple assessment of the palpable breast lump. Robinson's cytological grading can be done in fine needle cytology smears of breast lump. The aim of this study is to grade breast tumor on cytology according to Robinson cytological grading and to correlate with histopathological grading.
\end{abstract}

Materials and Methods: This prospective study was done in Department of pathology, Bhaktapur Cancer Hospital from $1^{\text {st }}$ April 2014 to $30^{\text {th }}$ July 2015. A total of 58 cases of cytologically confirmed breast carcinoma were included in this study and correlated with histopathological findings. Robinson's cytological grading was done on cytology smears and modified Bloom-Richardson grading was done on histological sections. Correlation between these two grading was done by using spearman's correlation coefficient.

Results: Cytologically, most common tumor was grade II (62.1\%) followed by grade I (19\%) and grade III (19\%). Histologically, most common tumor was grade II (63.8\%) followed by grade III (22.4\%) and grade I (13.8\%). High concordance rate was found in grade II tumor (80\%) with absolute concordance being $65.9 \%$. On cytology, cell dissociation and nuclear margin were determining features $(\mathrm{p}<0.005)$. Correlation between cytological grading and histological grading was statistically significant $(\mathrm{p}<0.005)$.

Conclusion: : Robinson's cytological grading is the easy grading method that can be done on cytology smears of the breast carcinoma to achieve relevant information regarding aggressiveness of the tumor and to plan for neoadjuvant chemotherapy preoperatively.

\section{INTRODUCTION}

Invasive breast carcinoma is a most common carcinoma in women. It accounts for $23 \%$ of female, $27 \%$ in affluent

\author{
Correspondence: \\ Dr. Sanat Chalise, $M D$ \\ Department of Pathology, \\ Kathmandu Medical College, Kathmandu, Nepal. \\ E-mail: sanatchalise@hotmail.com,sanat_chalise@yahoo.com
}

countries, which is more than twice the occurrence of cancer in women at any other site. ${ }^{1}$ From the hospital based cancer registry of Nepal, which contains pooled data from seven major hospitals where cancer is diagnosed and treated, there were a total of 2910 cancer patients in the year 2009, 211 of these were breasts cancers, which represent $7.2 \%$ of all malignancies, and is the second most commonly diagnosed cancer in Nepal. ${ }^{2}$ Cancer education, screening and early detection are the key elements to influence the diagnosis, 
Table 1: Cytological grading according to Robinson's Grading system

\begin{tabular}{llll}
\hline \multicolumn{1}{c}{ Score } & $\mathbf{1}$ & $\mathbf{2}$ & $\mathbf{3}$ \\
\hline Cell dissociation & Cells mostly in clusters & Mixture of single cells and clusters & Mostly single cells \\
Cell size & $1-2$ times size of RBC & $3-4$ times size of RBC & $>=5$ times size of RBC \\
Cell uniformity & Monomorphic & Mildly Pleomorphic & Pleomorphic \\
Nucleoli & Indistinct & Noticeable & Prominent or pleomorphic \\
Nuclear margin & Smooth & Slightly irregular/folds and grooves & Buds and clefts \\
Chromatin & Vesicular & Granular & Clumped and cleaved
\end{tabular}

treatment and prognosis of breast cancer in Nepal. ${ }^{3}$

Fine needle aspiration cytology (FNAC) is an important of the triple assessment of palpable breast lump. It has been shown than the FNAC can reduce the number of open biopsies. ${ }^{4}$ The standard prognostic factors, recognized by the National Cancer Institute in 1990, include lymph node status, tumor size, nuclear grade, steroid receptor content, tumor type, and cellular proliferation rate and recommend that for patients who undergo preoperative chemotherapy or radiotherapy, breast fine-needle aspirates
Table 2: Histological grading of breast carcinoma (modified Bloom-Richardson grading)

\begin{tabular}{lccc}
\hline Score & $\mathbf{1}$ & $\mathbf{2}$ & $\mathbf{3}$ \\
\hline Tubule formation & $\begin{array}{c}>75 \% \text { of } \\
\text { tumor }\end{array}$ & $\begin{array}{c}10-75 \% \text { of } \\
\text { tumor }\end{array}$ & $\begin{array}{c}<10 \% \text { of } \\
\text { tumor }\end{array}$ \\
$\begin{array}{l}\text { Nuclear pleomorphism } \\
\text { Mitotic count (per 10 } \\
\text { high power field) }\end{array}$ & $0-9$ & $10-19$ & $>20$ \\
\hline
\end{tabular}

Table 3: Evaluation of cytological features on cytological and histological grade

\begin{tabular}{|c|c|c|c|c|c|c|}
\hline \multirow{2}{*}{ Cytological score } & \multicolumn{3}{|c|}{ Cytological grade } & \multicolumn{3}{|c|}{ Histological grade } \\
\hline & Grade I & Grade II & Grade III & Grade I & Grade II & Grade III \\
\hline \multicolumn{7}{|l|}{ Cell dissociation } \\
\hline Mostly clusters & 9 & 11 & 0 & 6 & 13 & 1 \\
\hline Single cells and clusters & 2 & 22 & 7 & 2 & 20 & 9 \\
\hline Mostly single cells & 0 & 3 & 4 & 0 & 4 & 3 \\
\hline \multicolumn{7}{|l|}{ Cell size } \\
\hline 1-2 times size of RBC & 7 & 3 & 0 & 4 & 6 & 0 \\
\hline 3-4 times size of RBC & 4 & 15 & 0 & 4 & 12 & 3 \\
\hline$>=5$ times size of $\mathrm{RBC}$ & 0 & 18 & 19 & 0 & 19 & 10 \\
\hline \multicolumn{7}{|l|}{ Cell Uniformity } \\
\hline Monomorphic & 7 & 2 & 0 & 6 & 3 & 0 \\
\hline Mildly Pleomorphic & 4 & 29 & 5 & 2 & 29 & 7 \\
\hline Pleomorphic & 0 & 5 & 6 & 0 & 5 & 6 \\
\hline \multicolumn{7}{|l|}{ Nucleoli } \\
\hline Indistinct & 9 & 4 & 0 & 6 & 6 & 1 \\
\hline Noticeable & 2 & 19 & 1 & 1 & 18 & 3 \\
\hline Prominent or pleomorphic & 0 & 13 & 10 & 1 & 13 & 9 \\
\hline \multicolumn{7}{|l|}{ Nuclear margin } \\
\hline Smooth & 10 & 3 & 0 & 4 & 8 & 1 \\
\hline $\begin{array}{l}\text { Slightly irregular/folds and } \\
\text { grooves }\end{array}$ & 1 & 31 & 5 & 4 & 26 & 7 \\
\hline Buds and clefts & 0 & 2 & 6 & 0 & 3 & 5 \\
\hline \multicolumn{7}{|l|}{ Chromatin } \\
\hline Vesicular & 6 & 3 & 0 & 4 & 4 & 1 \\
\hline Granular & 5 & 28 & 3 & 4 & 26 & 6 \\
\hline Clumped and clear & 0 & 5 & 8 & 0 & 7 & 6 \\
\hline
\end{tabular}


Table 4: Distribution of cases according to Robinson's cytological grading system

\begin{tabular}{|c|c|c|}
\hline Cytological grade & $\begin{array}{c}\text { Number of } \\
\text { cases }\end{array}$ & Percentage \\
\hline Grade I & 11 & $19 \%$ \\
\hline Grade II & 36 & $62.1 \%$ \\
\hline Grade III & 11 & $19 \%$ \\
\hline
\end{tabular}

Table 5: Distribution of cases according to modified BloomRichardsongrading system

\begin{tabular}{lcc}
\hline Histological grade & $\begin{array}{c}\text { Number } \\
\text { cases }\end{array}$ & of \\
\hline Grade I & 8 & $13.8 \%$ \\
\hline Grade II & 37 & $63.8 \%$ \\
\hline Grade III & 13 & $22.4 \%$ \\
\hline
\end{tabular}

Table 6: Concordance rate of cytological grading and histological grading

\begin{tabular}{lccccc}
\hline Robinson's cytological grade & \multicolumn{3}{c}{ Histological grade } & Total & Concordance rate \\
\hline & Grade I & Grade II & Grade III & & \\
Grade I & 5 & 5 & 1 & $11(19 \%)$ & $45 \%$ \\
Grade II & 3 & 29 & 4 & $36(62.1 \%)$ & $80 \%$ \\
Grade III & 0 & 3 & $11(19 \%)$ & $72.7 \%$ \\
Total & $8(13.8 \%)$ & $37(63.8 \%)$ & $13(22.4 \%)$ & 58 & $65.9 \%$
\end{tabular}

Table 7: Correlation of cytological features with cytological grade using Univariate analysis

\begin{tabular}{lcc}
\hline Cytological Grade & $\begin{array}{c}\text { Spearman correlation } \\
\text { coefficient }\end{array}$ & p-Value \\
\hline Cell dissociation & 0.569 & 0.000 \\
Cell size & 0.669 & 0.000 \\
Cell uniformity & 0.619 & 0.000 \\
Nucleoli & 0.685 & 0.000 \\
Nuclear margin & 0.755 & 0.000 \\
Chromatin & 0.641 & 0.000 \\
\hline
\end{tabular}

can be used toprovide prognostic information. ${ }^{5}$ Cytological grading of breast carcinoma, which is a simple, feasible and reproducible method, can be used for selection of neoadjuvant therapy and would allow the assessment of the tumors without any surgical intervention so that the morbidity associated with overtreatment of low-grade tumors can be avoided. ${ }^{6}$ The concept of nuclear grading in breast carcinoma was introduced by Black et $\mathrm{al}^{7}$ in 1955 . It was applied in cytological smears after modification by Fisher et $\mathrm{al}^{8,9}$ or after simplification by Cajuliset al. ${ }^{10}$

Histopathological grading of breast carcinoma using modified Bloom-Richardson grading system is a widely accepted tumor grading system and has been found to have good prognostic correlation. Based on the cytological features, various grading systems have evolved. Of the different cytological grading methods corresponding to modified Bloom-Richardson grading, the Robinson's cytological grading was found to be useful in grading breast carcinoma in FNAC. ${ }^{11}$

The purpose of the present study was to compare cytological grading using Robinson's method with histological grading using modified Bloom-Richardson grading method.
Table 8: Multiple regression analysis of cytological grade

\begin{tabular}{lcc}
\hline & $\begin{array}{c}\text { Regression } \\
\text { coefficient }\end{array}$ & p-Value \\
\hline (Constant) & -.320 & .063 \\
Cell dissociation & .263 & .000 \\
Cell size & .099 & .176 \\
Cell uniformity & .072 & .417 \\
Nucleoli & .104 & .154 \\
Nuclear margin & .415 & .000 \\
Chromatin & .221 & .013 \\
\hline
\end{tabular}

\section{MATERIALS AND METHODS}

This was a prospective study done in department of pathology, Bhaktapur cancer hospital, Nepal from $1^{\text {st }}$ April 2014 to $30^{\text {th }}$ July 2015. 58 cases with cytologically confirmed breast carcinoma were included in this study and correlated with histopathological findings. FNAC of breast lump was done with 22 gauge needle which were attached to $10 \mathrm{ml}$ syringes. Smears made were stained with Giemsa as well as Hematoxylin and Eosin stain (H\&E). The cytological grading was done by Robinson's method in which the cell dissociation, nuclear size, cell uniformity, nucleoli, nuclear margins and the chromatin patterns were studied (Table 1). The lumpectomy and mastectomy specimens of the corresponding cases were fixed in $10 \%$ formalin, routinely processed and stained with $\mathrm{H} \& \mathrm{E}$ stain. Histolopathological grading was done according to modified Bloom-Richardsongrading method in which tubule formation, nuclear pleomorphism and mitotic count were evaluated (Table 2).

Correlation between Robinsons cytological and modified Bloom-Richardson histopathological grading was done. Data was analysed using the statistical package for social science (SPSS) and final correlation was established using 
Table 9: Correlation of histological features with histological grade using Univariate analysis

\begin{tabular}{lcc}
\hline \multirow{2}{*}{ Histological features } & \multicolumn{2}{c}{ Spearman's correlation coefficent } \\
\cline { 2 - 3 } & $\mathrm{r}$-value & $\mathrm{p}$-value \\
Tubule & .575 & .000 \\
Pleomorphism & .584 & .000 \\
Mitosis & .641 & .000 \\
\hline
\end{tabular}

Table 11: Correlation of cytological grading with Histological grading

\begin{tabular}{lcc}
\hline & \multicolumn{2}{c}{ Spearman's correlation coefficent } \\
\cline { 2 - 3 } & r-value & p-value \\
$\begin{array}{l}\text { Cytological Grade and } \\
\text { Histological Grade }\end{array}$ & .575 & .000 \\
\hline
\end{tabular}

Spearman's correlation coefficient.

\section{RESULTS}

A total number of 58 cases were included in this study, aged between 27 years and 80 years. Mean age was 46.12 years. Cytological scores were analyzed using cytological grade and histological grade and the details are shown in Table 3, Figure 1, 2 and 3.

In this study, using Robinson's cytological grading, maximum number of carcinoma were grade II $(62.1 \%)$, followed by grade I (19\%) and grade III (19\%) as shown in Table 4. Using histopathological grading, maximum numbers of cases were grade II (63.8\%), followed by Grade III (22.4\%) and Grade I (13.8\%) as shown in Table 5.

The absolute concordance rate was $65.9 \%$ (Table 6). The highest concordance rate of $80 \%$ was found in Grade II tumor.

\section{DISCUSSION}

FNAC may be performed as the first-line investigation, especially in symptomatic and screening populations. The main purpose of FNAC of breast lumps is to confirm cancer preoperatively and to avoid unnecessary surgery. ${ }^{12}$ Among the various cytological grading systems, Robinson's system is simple, more objective, takes little time and effort, is reproducible and correlates precisely with modified BloomRichardson histological grade. ${ }^{6}$

Cytological grade and histological grade was evaluated according to the Robinson's cytological features. In the current study, the majority of the cases were Grade II (62.1\%) followed by Grade I (19\%) and Grade III (19\%) cytologically.Histologically, commonest tumor was Grade II (63.8\%) followed by Grade III (22.4\%) and Grade I (13.8\%). Sood N et al5, Gore CR et $\mathrm{al}^{13}$ and Phukan JP et
Table 10: Multiple regression analysis of Histological grade

\begin{tabular}{lcc}
\hline & $\begin{array}{c}\text { Regression } \\
\text { coeffcient }\end{array}$ & p-value \\
\hline (Constant) & -.274 & .106 \\
Tubule & .405 & .000 \\
Pleomorphism & .312 & .000 \\
Mitosis & .398 & .000
\end{tabular}

Table 12: Comparative table on cytological grading and histological grading in relation to the present study

\begin{tabular}{lc}
\hline Study done by & p-value \\
\hline Present study & 0.000 \\
Rajan J and Pai KP14 & 0.000 \\
Lingegowda et al18 & $<0.001$ \\
Frias et al21 & $<0.0005$
\end{tabular}

$\mathrm{al}^{11}$ also found grade II as a commonest tumor on cytological grading and histological grading, whereas Rajan J and Pai $\mathrm{KP}^{14}$ in their study found grade I as a commonest tumor.

Present study showed, absolute concordance rate of $65.9 \%$ which is comparable with the study done by Sood $\mathrm{N}$ et al ${ }^{5}$, Phuken et $\mathrm{al}^{11}$ and Das et $\mathrm{al}^{15}$ where they found absolute concordance rate of $68.97 \%, 72.2 \%$ and $69 \%$ respectively. The highest concordance rate of $80 \%$ was found in Grade II tumor in our study which was similar to the study done by Phukenet al ${ }^{11}$ where they found $83 \%$ concordance rate in grade II and grade III tumor. But in contrast to this study, Sood $\mathrm{N}$ et $\mathrm{al}^{5}$ found highest concordance rate in grade I tumor $(75 \%)$.

The highest level of disconcordance was found in grade I tumor in our study which is similar to the study done by Phukanet $\mathrm{al}^{11}$ however sood $\mathrm{N}$ et $\mathrm{al}^{5}$ found highest level of disconcordance in Grade III tumor. The cause of disconcordance may be because of subjective variation during assessment of cytological features that are not the features of histological grading. Dabbas DJ et $\mathrm{al}^{16}$ and Howell LP et al ${ }^{17}$ found difficult to assess tubule formation and mitotic index on cytology and conclude that the thedisconcordance may be due to the disparities between cytological and histological features.

In our study, using univariate analysis, all of the cytological features show strong correlation with cytological grade $(\mathrm{p}<0.005)$ however the multiple regression analysis show cell dissociation and nuclear margin as a most important influencable factor. All histological features shown strong correlation and influence in histological grading. Das et $\mathrm{al}^{15}$ also found strong correlation between cytological features and cytological grade with cell dissociation, nuclear margin, nucleoli and uniformity as a most influencable factor. Similarly study done by Lingegowdaet $\mathrm{al}^{18}$ found strong correlation between cytological features and cytological grade with cell dissociation, nucleoli and nuclear margin 

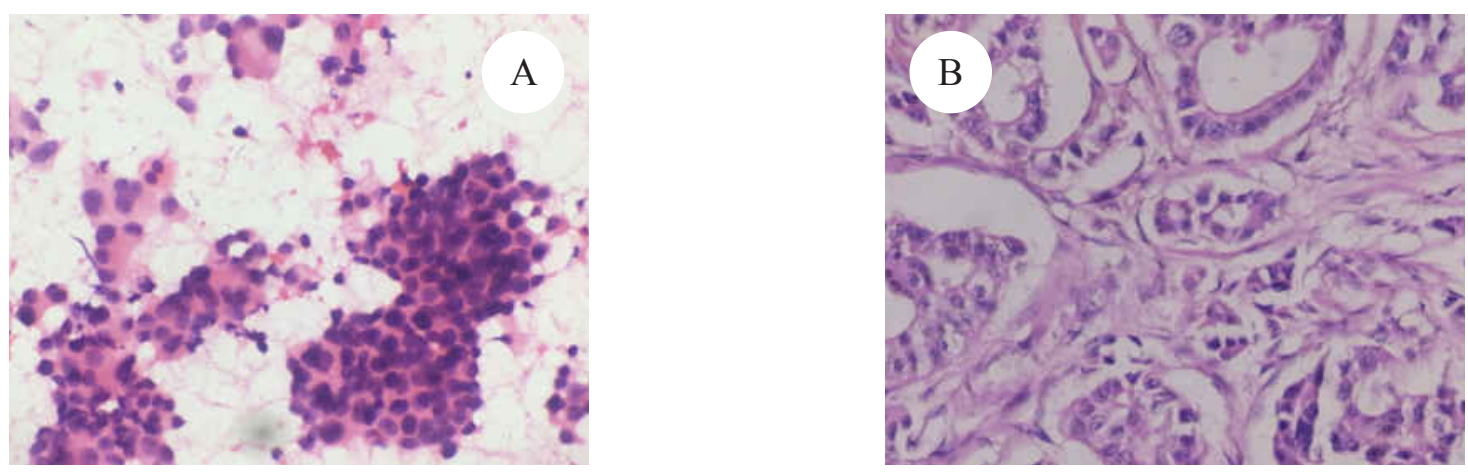

Figure1(a): Robinson's grade I. Uniform cells with fine nuclear chromatin, smooth nuclear margin and inconspicious nucleoli (Hand E Stain, X400). Figure 1(b): Modified Bloom-Richardson grade I, score 5 of the same patient showing tubules with mildly pleomorphic nuclei (H\& E stain, X400).
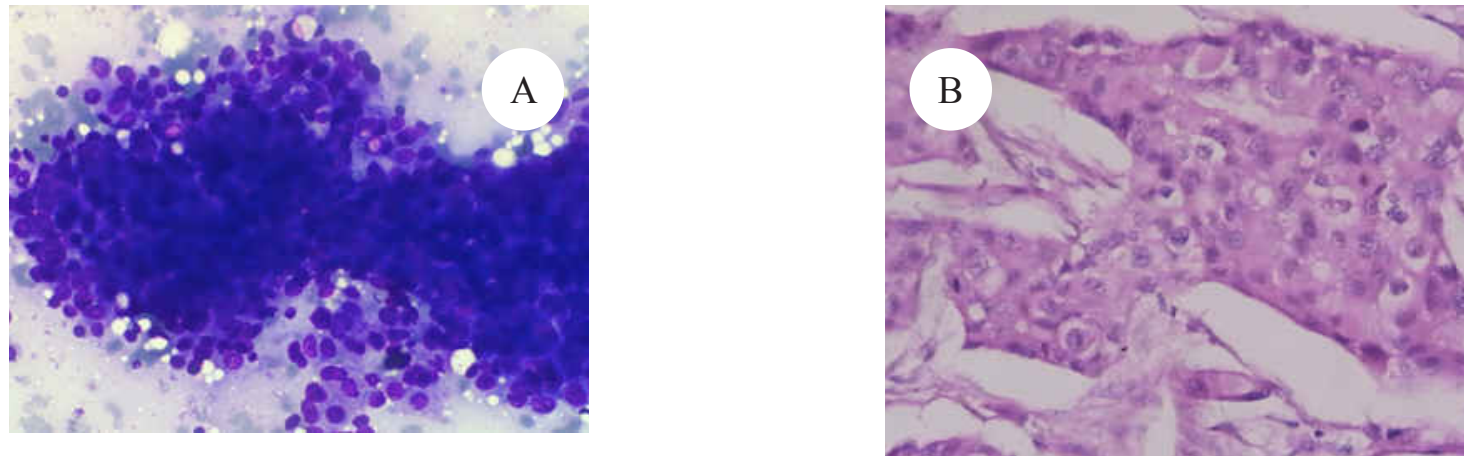

Figure2(a): Robinson's grade II. Mildly pleomorphic cells with granular nuclear chromatin, slightly irregular nuclear margin and noticeable nucleoli in few cells (Giemsa Stain, X400). Figure 2(b): Modified Bloom-Richardson grade II, score 7 of the same patient showing absence of tubules with moderately pleomorphic nuclei and mitotic figure (H\& E stain, X400).
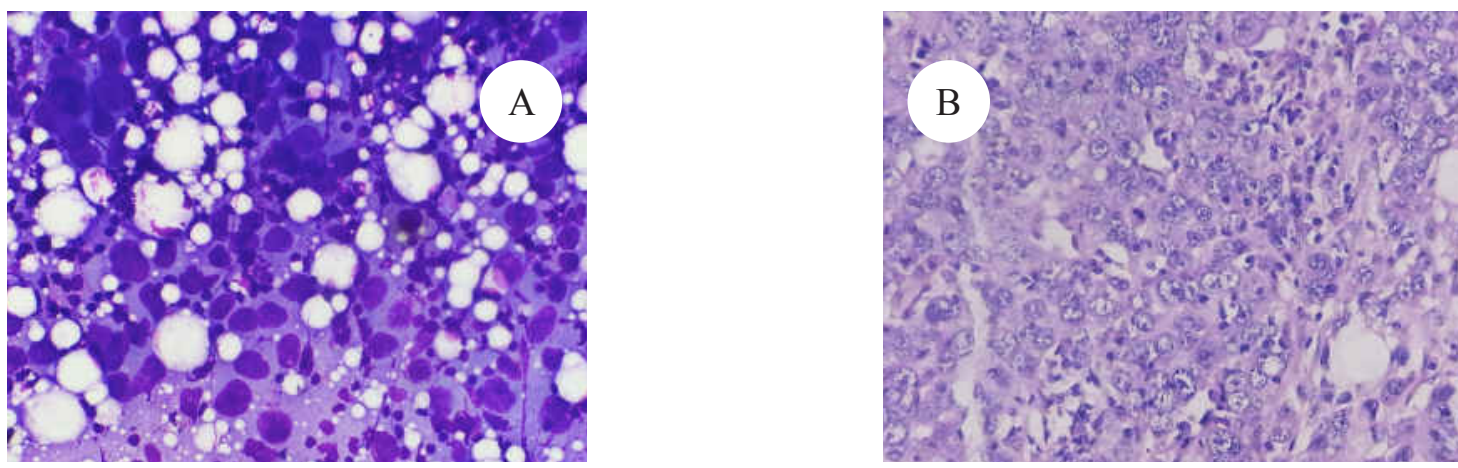

Figure3(a): Robinson's grade III. Markedly pleomorphic cells with clumped nuclear chromatin, irregular nuclear margin and prominent nucleoli (Giemsa Stain, X400). Figure 3(b): Modified Bloom-Richardson grade III, score 9 of the same patient showing absence of tubules with markedly pleomorphic nuclei (H and E stain, X400).

as a most influencable factor. Rajan J and Pai $\mathrm{KP}^{14}$ in their study also found significant statistical correlation between cytological features and cytological grade however in contrary to our study they found cell size, uniformity and nucleoli as a most influencable factor.

Cell dissociation is found to be an important cytological feature as several studies showed an association between increase in cell dissociation and incidence of lymphnode metastasis as cell cohesion status and expression of
E-Cadherin are indicated by cell dissociation status thus helping in preoperative assessment of the patient. ${ }^{19,20}$

This study showed statistically significant correlation $(p<0.005)$ between cytological and histological grade which was similar to the study done by Rajan J et al ${ }^{14}$, lingegowda et $\mathrm{al}^{18}$ and Frias et $\mathrm{al}^{21}$. Table 12 showed the cytological and histological correlation between various studies in relation to our studies. 
All the cytological features are statistically significant using Univariate analysis (Table 7). Cell dissociation and nuclear margin were found to be the most influencable factors using Multiple regression analysis (Table 8 ). Similarly all the histological features are statistically significant using Univariate analysis and all the histological features have equal influence in histopathological grading (Table 9 and 10)

\section{CONCLUSION}

Robinson's cytological grading is a simple, feasible and easily reproducible method of assessing breast carcinoma preoperatively. This cytological grading method can be done preoperatively to determine the aggressiveness of the tumor and to plan for the neoadjuvant chemotherapy.

\section{REFERENCES}

1. Colditz G, Chia K.S. Invasive breast carcinoma: Introduction and general features, In: Lakhani SR, Ellis IO, Schnitt SJ, Tan PH, Van de vijver MJ (eds). World health Organization classification of tumours Pathology and genetics tumours of the breast. 4th ed. IARC: Lyon; 2005. pp 14-30.

2. Acharya SC, Jha AK, Manandhar T. Clinical profile of patients presenting with breast cancer in Nepal. Kathmandu Univ Med J 2012;39:3-7.

3. Singh YP, Sayami P. Management of breast cancer in Nepal. J Nepal med Assoc. 2009; 48:252-7. Crossref

4. Thakkar B, Parekh M, Trivedi NJ, Agnihotri AS, Mangar U. Role of Fine needle aspiration cytology in palpable breast lesions and its correlation with histopathological diagnosis. National journal of medical research. 2014;4:283-8.

5. Sood N, Nigam JS, Yadav P et al. Comparative study of cytomorphological Robinson's grading of breast carcinoma with Modified Bloom-Richardson histopathological grading. Pathology research international. 2013;146542:1-5. Crossref

6. Saha K, Raychaudhuri G, Chattopadhyay BK, Das I. Comparative evaluation of six cytological grading systems in breast carcinoma. J cytol 2015;30:87-93. Crossref

7. Black MM, Opler SR, Speer FD. Survival in breast cancer cases in relation to the structures of primary tumor and regional lymphnodes. SurgGynecol Obstet. 1955;100:543-51. Crossref

8. Fisher ER, Redmond C, Fisher B. Histologic grading of breast cancer. PatholAnnu. 1980;15:239-51.Crossref

9. Fisher ER, Gregorio RM, Fisher B, Redmond C, Vellious F, Sommers
SC. The pathology of invasive breast cancer. A syllabus derived from findings of National surgical adjuvant breast project (protol No. 4) Cancer 1975;36:1-85. Crossref

10. Cajulis RS, Hessel RG, Hwang S, Haines K, Frias-Hidvegi D, O'Gorman M. Simplified nuclear grading of fine needle aspirates of breast carcinoma: concordance with corresponding histologic nuclear grading and flow cytometric data. DiagnCytopathol. 1994;11:124-30. Crossref

11. Phukan JP, Sinha A, Deka JP. Cytological grading of breast carcinoma on fine needle aspirates and its relation with histological grading. South Asian J cancer. 2015;4:32-4. Crossref

12. Lindholm K. Breast, In: Orell SR, Sterrett GF, Whitaker D (eds). Fine needle aspiration cytology. 4thedn. Churchill Livingstone: 2005. pp165-225.

13. Gore CR, Chandanwale SS, Aggarwal R, Vimal S, Deshpande AH. Robinson cytological grading of breast carcinoma on fine needle aspiration cytology-An overview. International journal of pharmacy and biological sciences. 2013;3: 564-70.

14. Rajan J, Pai KP. Robinson's cytological grading of breast carcinoma and its correlation with Scarff Bloom Richardson's histological grading. International journal of biomedical research. 2014;5:105-9. Crossref

15. Das S, Kalyani, Kumar H. Breast carcinoma aspirates: a study on cytological grading. International journal of basic and applied medical sciences. 2012;2:189-95.

16. Dabbs DJ, Silverman JF. Prognostic factors from the fine needle aspirate: breast carcinoma nuclear grade. DiagnCytopathol. 1994;10:203-8. Crossref

17. Howell LP, Gandour-Edwards R, O'Sullivan D. Application of the Scarff-Bloom-Richardson tumor grading system to fine needle aspirates of the breast. Am J ClinPathol. 1994;101:262-5. Crossref

18. Lingegowda B, MuddeGowda H, Ramakantha K, Chandrasekar R. Cytohistological correlation of grading in breast carcinoma. DiagnCytopathol. 2011;39:251-7. Crossref

19. Bhargava V, Jain M, Agrawal K, Thomas S, Singh S. Critical appraisal of cytological nuclear grading in carcinoma of the breast and its correlation with ER/PR expression. J cytol. 2008;25:58-61. Crossref

20. Robinson IA, McKee G, Nicholson A et al. Prognostic value of cytological grading of fine needle aspirates from breast carcinomas. The Lancet. 1994;343:947-9. Crossref

21. Robles-Frias A, Gonzalez-campora R, Martinez-Parra D et al. Robinson cytologic grading of invasive ductal breast carcinoma. Correlation with histologic grading and regional lymphnode 
metastasis. ActaCytol. 2005;49:149-53. Crossref 